\title{
Pengolahan Limbah Minyak Jelantah dan Kulit Pisang Menjadi Sabun
}

\author{
Vera Yuli Erviana ${ }^{1}$, Iis Suwartini ${ }^{1}$, Ahmad Ahid Mudayana ${ }^{1}$ \\ ${ }^{1}$ Universitas Ahmad Dahlan, Yogyakarta, Indonesia \\ Email koresponden: vera.erviana@pgsd.uad.ac.id
}

\begin{abstract}
Abstrak
Limbah minyak jelantah dan kulit pisang di Desa Sendangsari cukup banyak. Hal tersebut dikarenakan banyaknya warga yang berprofesi sebagai penjual kuliner geblek ( sejenis gorengan yang dibuat dari tepung pati) ditambah lagi minyak jelantah yang dihasilkan dari rumahan. Melimpahnya sumber daya alam pisang dapat dimanfaatkan tidak hanya buahnya tetapi kulit pisang juga dapat digunakan sebagai penjernih minyak jelantah. Berdasarkan permasalahan tersebut maka limbah minyak jelantah dan limbah kulit pisang diolah untukmenjadi sabun cuci tangan dengan berbagai modivikasi sehingga dapat dijadikan cendramata dan souvenir pernikahan. Metode yang digunakan yaitu sistem pengolahan limbah berbasis zero waste industry. Konsep zero waste industry terdiri dari reduce (mengurangi), reause (menggunakan kembali) dan recycle (mendaur ulang). Kegiatan tersebut terdiri dari: 1) penyuluhan limbah minyak jelantah bagi lingkungan, 2) membentuk UMKM mandiri dan memprakarsai tabungan minyak jelantah, 3) pembuatan buku pengolahan limbah minyak jelantah dan strategi pemasaran 4) pelatihan penjernihan minyak jelantah, 5) pelatihan pengolahan limbah minyak jelantah menjadi sabun mandi, 6) pelatiahan SDM dalam kewirausahaan, 8) dan pendampingan perijinan. Luaran yang dihasilkan berupa teknik pengelolaan limbah minyak jelantah berbasis Zero Waste Industry, produk sabun cuci tangan, dan peningkatan kesadaran akan lingkungan serta terciptanya lapangan pekerjaan.
\end{abstract}

Kata kunci: minyak jelantah, kulit pisang, sabun.

\begin{abstract}
Waste of used cooking oil and banana peels in Sendangsari Village are quite a lot. This is because many people made geblek (a type of fried food made from starch) to be sold, and also there are a lot of cooking oil waste from home. The abundance of natural resources of banana can be used not only for the fruit, but also the banana peels can also be used as the purifier of cooking oil waste. Therefore, used cooking oil and banana peel waste are processed to become handwash soap, and also with various modifications can be used as souvenirs and wedding souvenirs. The method used was a waste treatment system based on zero waste industry. The zero waste industry concept consisted of reduce, reause, and recycle. The activities consisted of: 1) education on waste cooking oil in the environment, 2) establishing independent MSME management and initiating used cooking oil savings, 3) making books of used cooking oil treatment and marketing strategy, 4) training on purifying used cooking oil waste, 5) training on processing cooking oil waste into bath soap, 6) HR training in entrepreneurship, 8) and licensing assistance. The outcomes is used cooking oil waste management techniques based on Zero Waste Industry, handwash soap products, and increasing awareness of the environment and creating jobs.
\end{abstract}

Keywords: cooking oil waste, banana peel, soap.

Format Sitasi: Erviana V.Y., Suwartini I, Mudayana A.A. (2018). Pengolahan Minyak Jelantah dan
Kulit Pisang Menjadi $\quad$ Sabun.
http://dx.doi.org/10.29405/solma.v7i2.2003.

Diterima: 04 April 2018 | Revisi: 28 September 2018 | Dipublikasikan: 30 Oktober 2018 


\section{PENDAHULUAN}

Buah pisang merupakan buah yang kaya akan manfaat tidak hanya buahnya kulit pisang pun dapat dimanfaatkan untuk menjernihkan minyak jelantah. Pisang merupakan buah yang banyak ditemui pada negara beriklim tropis, tak heran buah pisang di Indonesia sangat melimpah. Desa Sendangsari merupakan salah satu dusun yang banyak memiliki pohon pisang. Pada umumnya masyarakat menggunakan buah pisang untuk dikonsumsi maupun dijual namun pengolahan kulit pisang belum optimal. Hal tersebut sangat disayangkan ketidaktahuan masyarakat tentang manfaat kulit pisang. Kulit pisang bersifat absorben artinya menyerap zat lain pada permukaannya tanpa reaksi kimia. Kulit pisang dapat dimanfaatkan untuk menjernihkan minyak jelantah.

Minyak goreng yang telah digunakan biasa disebut dengan minyak jelantah (waste cooking oil) pernyataan tersebut juga dikemukakan (Putra, 2012). Minyak Jelantah merupakan limbah karena bilangan asam dan peroksidanya meningkat dan mengandung senyawa karsinogenik selama proses penggorengan (Yusuf, 2010). Tidak Jauh berbeda dengan (Aminah, 2010) selama penggorengan terjadi hidrolisis, oksidasi, pirolisis, dekomposisi minyak yang dipengeruhi oleh bahan pangan dan kondisi penggorengan.

Minyak jelantah bisa diolah kembali melewati sistem filterisasi, hingga warnanya kembali jernih serta seolah layaknya minyak goreng baru, tetapi kandungannya tetap mengaalami kerusakan hingga tidak baik untuk tubuh (Suryandari, 2014). Berdasarkan penelitian Suryani maka kami tidak menggunakan minyak jelantah hasil filterisasi untuk dikonsumsi melainkan digunakan untuk membuat sabun cuci tangan dengan kemasan souvenir. Sebelum dijadikan bahan baku pembuatan sabun kami menjernihkan terlebih dahulu dengan pisang kepok. Berdasarkan pendapat (Kasyfita, 2007) kulit pisang yang paling baik digunakan ialah kulit pisang kepok. Kami pun menggunakan kulit pisang kepok untuk mejernihkan limbah minyak jelantah di Desa Sendangsari. Kulit pisang yang sudah di oven atau dijemur terik matahari dapat direndam ke dalam minyak jelantah kurang lebih 3 hari. Minyak jelantah yang sudah direndam dengan kulit pisang dapat mengurangi kadar asam lemak jenuh yang bisa berdampak bagi kesehatan dan memperbaiki kualitas minyak.

Limbah minyak jelantah dan limbah kulit pisang merupakan limbah rumah tangga yang dapat diolah kembali menjadi barang yang bernilai. Masyarakat kini dapat meminimalisasi pembuangan kedua limbah tersebut dengan menerapkan zero waste industry. Kedua limbah tersebut dapat diolah menjadi bahan baku pembuatan sabun. 
Pemberdayaan masyarakat dalam pengolahan limbah minyak jelantah dan kulit pisang di Desa Sendangsari bertujuan untuk: (1) meminimalisasi pembuangan minyak jelantah disembarang tempat, (2) berubahnya pola hidup masyarakat untuk mengolah limbah minyak jelantah berbasis zero waste industry, (3) berkurangnya pembuangan minyak jelantah disembarang tempat dapat mengurangi resiko pencemaran air tanah. (4) terciptanya produk sabun bernilai ekonomis.

\section{MASALAH}

Kelurahan Sendangsari merupakan salah satu kelurahan yang terletak di Kecamatan Pengasih Kabupaten Kulon Progo Provinsi Daerah Istimewa Yogyakarta. Daerah ini merupakan salah satu daerah yang dekat dengan wisata Kali Biru di Kulon Progo. Mata pencaharian penduduknya adalah petani, pedagang, nelayan, buruh, peternak, dan wiraswasta. Mayoritas mata pencaharian warga Kelurahan Sendangsari masyarakat di daerah ini adalah petani. Bersarakan sumber yang kami peroleh dari web, jumlah petani perkebunan cukup banyak berjumlah 1947 rata-rata memiliki pohon pisang di kebun mereka. Buah pisang merupakan salah satu potensi alam yang mudah diperoleh di wilayah Kelurahan Sendangsari. Buah pisang pada umumnya diolah untuk makanan tradisional namun limbah kulit pisang belum dimanfaatkan secara optimal.

Warga Sendangsari yang berprofesi sebagai pedagang sekitar 161 orang. Sebagian dari mereka menekuni usaha kuliner seperti sriping pisang, emping garut (terbuat dari ubu garut), dan pathilo (rengginang singkong). Home industry tersebut tentunya menghasilkan limbah minyak jelantah yang cukup banyak belum lagi di tambah dengan limbah minyak jelantah yang berasal dari rumah tangga. 
Tabel 1. Jumlah Warga di Kelurahan Sendangsari

\begin{tabular}{llccccc}
\hline No & Nama Dusun & $\begin{array}{c}\text { Jumlah } \\
\text { RT }\end{array}$ & Jumlah KK & Jiwa & Lk & Pr \\
\hline 1 & Blubuk & 5 & 189 & 573 & 272 & 301 \\
2 & Gegunung & 10 & 285 & 870 & 412 & 458 \\
3 & Giri Nyono & 1 & 1 & 3 & 1 & 2 \\
4 & Girinyono & 7 & 370 & 1171 & 594 & 577 \\
5 & Jl. R. Merunggi & 1 & 1 & 1 & 1 & 0 \\
6 & Klegen & 7 & 393 & 1222 & 608 & 614 \\
7 & Kroco & 6 & 281 & 965 & 479 & 486 \\
8 & Mrunggi & 8 & 343 & 1113 & 553 & 560 \\
9 & Paingan & 8 & 401 & 1307 & 653 & 654 \\
10 & Pereng & 6 & 231 & 709 & 339 & 370 \\
11 & Secang & 8 & 315 & 951 & 459 & 492 \\
12 & Serang & 9 & 320 & 1005 & 498 & 507 \\
& TOTAL & 76 & 3130 & 9890 & 4869 & 5021 \\
\hline
\end{tabular}

Sumber:http://sendangsari.pengasih.kulonprogokab.go.id/sendangsari/index.php/first/statistik/1.

Limbah minyak jelantah yang dihasilkan dari rumah tangga di Dusun Mrunggi, Secang, dan Serang cukup banyak. Dusun Mrunggi memiliki jumlah 232 KK masingmasing rumah tangga menghasilkan $1 / 2$ liter per hari. Total keseluruhan limbah minyak jelantah $231 \times 1 / 2$ liter $=115,5$ liter perhari. Dusun Secang memiliki jumlah $315 \mathrm{KK}$ masing-masing rumah tangga menghasilkan $1 / 2$ liter per hari. Total keseluruhan limbah minyak jelantah 315 x1/2 liter $=157,5$ liter per hari. Dusun Serang memiliki jumlah 320 KK masing-masing rumah tangga menghasilkan $1 / 2$ liter per hari. Total keseluruhan limbah minyak jelantah $320 \times 1 / 2$ liter $=$ liter160 perhari. Limbah minyak jelantah tentunya akan berdampak buruk bagi kesehatan jika digunakan berulang kali. Pembuangan limbah minyak jelantah disembarang tempat seperti di saluran air dan tanah dapat mengakibatkan pencemaran air tanah. Apabila hal tersebut dibiarkan tentunya dapat mengancam ketersediaan air bersih.

\section{METODE PELAKSANAAN}

Berdasarkan identifikasi permasalahan yang dihadapi, maka diusulkan programprogram berdasarkan metode penyelesaian masalah yang sesuai dan relevan dengan permasalahan tersebut. Usulan penyelesaian masalah dijabarkan lebih lanjut di bawah ini dengan menyebutkan tujuan program, pihak yang terlibat, kelompok sasaran, mitra terkait dan indikator pencapaian hasil.

1. Sosialisasi Bahaya Limbah Minyak Jelantah.

Program ini bertujuan untuk memberikan sosialisasi atau penyuluhan dan pemahaman bahaya limbah minyak jelantah baik bagi kesehatan maupun lingkungan.. 
Program ini melibatkan kelompok PKK dan organisasi pemuda di Kelurahan Banaran. Mitra yang terlibat adalah Dinas Kesehatan Kabupaten Kulon Progo dan Dosen UAD. Indikator pencapaian program didasarkan pada pemahaman warga terhadap bahaya limbah minyak jelantah.

\section{Pembentukan Usaha Kecil Masyarakat (UKM)}

Program ini merupakan pembentukan Usaha Kecil Masyarakat (UKM) Mandiri di Kelurahan Sendangsari. UKM ini beranggotakan masyarakat di daerah Kelurahan Sendangsari. Pihak UKM inilah yang akan diajarkan pengelolaan limbah minyak jelantah mulai dari pengumpulan limbah minyak jelantah sampai pada pemasaran produk sabun mandi. UKM bersama kelompok PKK bertugas mengumpulkan limbah minyak jelantah melalui sistem (jemput bola) mendatangi rumah-rumah warga dan usaha kuliner untuk membeli limbah minyak jelantah dengan harga 3000 per liter. Hasil dari penjualan minyak jelantah kemudian dimasukan kedalam buku tabungan. Warga pun bisa menambil tabungan sewaktu-waktu. Mitra yang terlibat adalah pihak Kelurahan Sendangsari. Indikator keberhasilan program ini adalah terbentuknya UKM Mandiri dan sudah ada struktur organisasi dan tabungan minyak jelantah.

\section{Pelatihan Penjernihan Minyak Jelantah}

Penjernihan limbah minyak jelantah dengan menggunakan limbah kulit pisang merupakan solusi penjernihan yang ramah lingkungan dan ekonomis. Mitra yang terlibat dalam kegiatan ini adalah UKM Mandiri, organisasi pemuda dan kelompok PKK di Kelurahan Sendangsari. Indikaor keberhasilan program ini adalah pihak UKM Mandiri, organisasi pemuda, dan ibu-ibu PKK dapat melakukan penjernihan limbah minyak jelantah ramah lingkungan. Pelatihan Pengolahan Limbah Minyak Jelantah menjadi sabun berbasis Zero Waste Industry

4. Pembuatan sabun dari minyak jelantah

Pelatihan pengolahan limbah minyak jelantah menjadi sabun berbasis Zero Waste Industry bertujuan untuk menumbuhkan budaya cinta lingkungan. Pembuatan sabun berbasis Zero Waste Industry yang terdiri dari Reduce, Reuse dan Recycle (3R). Mitra yang terlibat dalam kegiatan ini adalah UKM Mandiri, organisasi pemuda dan kelompok PKK di Kelurahan Sendangsari. Indikator keberhasilan program ini dapat melakukan pengolahan limbah minyak jelantah menjadi sabun berbasis Zero Waste Industry.

5. Sosialisasi dan Pelatihan Teknik Kemasan Olahan Limbah Minyak Jelantah 
Program ini bertujuan untuk meningkatkan kemasan produk olahan limbah minyak jelantah yaitu sabun yang menarik menggunakan teknik desain kemasan sehingga dapat memberikan citra positif di mata konsumen. Program ini bersifat pemberdayaan masyarakat secara integratif. Indikator kepahaman dinilai menggunakan instrumen kuisioner sebelum dan sesudah penyuluhan, sedangkan ketrampilan mendesain kemasan produk olahan limbah minyak jelantah yaitu sabun dilihat dari hasil desain jadi. Mitra yang terlibat dalam kegiatan ini adalah UKM Mandiri, organisasi pemuda dan kelompok PKK di Kelurahan Sendangsari.

6. Penyusunan Penyuluhan dan Praktek Lapangan Teknik Survey Harga Standar Pasaran

Program ini bertujuan untuk memberikan pemahaman dalam menentukan harga standar yang kompetitif berbanding produk kompetitor melalui survei pasar dan efisiensi produksi. Sasaran program ini adalah pelaku usaha produk olahan limbah minyak jelantah. Setelah penyuluhan selesai, dilanjutkan dengan praktek lapangan di beberapa pasar, agen, dan penjual produk souvenir atau oleh-oleh khas daerah Kulon Progo. Mitra yang terlibat dalam program ini adalah Dinas Koperasi dan UMKM Kabupaten Kulon Progo dan Dosen Fakultas Kesehatan Masyarakat UAD. Indikator hasil dinilai dari tingkat pemahaman kelompok sasaran setelah mengikuti penyuluhan dan praktek lapangan, yaitu melalui presentasi dan diskusi hasil survei dari setiap kelompok sasaran. Pada kegiatan ini UKM bekerjasama dengan organisasi pemuda sebagai tim teknis survey harga standar pasaran.

\section{PEMBAHASAN}

Pelaksanaan kegiatan pelatihan pembuatan sabun dari limbah kulit pisang kepok dan limbah minyak jelantah ini dilaksanakan selama satu bulan di Desa Sendangsari Kecamatan Pengasih Kulonprogo. Teknis pelaksanaanya diawali dengan sosialisasi program, pembentukan UMKM, pelatihan penjernihan limbah minyak jelantah dengan kulit pisang kepok, pelatihan pembuatan sabun, pelatihan pengemasan sabun souvenir, penentuan harga sabun, perizinan produk, dan pemasaran produk.

Berikut ini langkah-langkah pembuatan sabun dari limbah minyak jelantah dan limbah pisang kepok. Pembuatan sabun dari limbah minyak jelantah diawali dengan penjernihan minyak jelantah dengan kulit pisang kepok sebanyak satu sisisr untuk $290 \mathrm{ml}$ minyak jelantah. Minyak jelantah yang sudah dioven dengan suhu $100^{\circ}$ celcius selama 15 menit kemudian direndam kedalam baskom yang berisi minyak jelantah sampai terlihat 
jernih sekitar 3-5 hari. Minyak jelantah yang sudah jernih siap digunakan untuk bahan pembuatan sabun.

Langkah pembuatan sabun sebagai berikut: (1) sediakan $\mathrm{NaOH} 36$ gram, (2) tuang air pada gelas bekker $73 \mathrm{ml}$, (3) masukan $\mathrm{NaOH}$ ke dalam air sedikit demi sedikit sembari di aduk perlahan ( catatan : selalu masukan $\mathrm{NaOH}$ ke dalam air), (4) setelah $\mathrm{NaOH}$ larut dalam air (jernih), ukur suhunya dengan termometer dan turunkan suhu hingga $\pm 29^{\circ} \mathrm{C}$ kemudian tambahkan pewarna makanan secukupnya, (5) Ukur minyak jelantah murni yang akan digunakan dengan teko bervolume, (6) Tambahkan pengharum pada minyak secukupnya, (7) Masukan minyak yang telah diberi pengharum ke dalam blender dan blenderlah \pm 5 detik / sekali berputar, (8) Masukan $\mathrm{NaOH}$ yang suhunya telah turun ke dalam blender minyak dan blenderlah \pm 5 detik / sekali berputar, (9) Setelah tercampur, masukan cairan sabun ke dalam cetakan dan tunggu \pm 3-4 jam hingga sabun menjadi padat. Sabun yang sudah jadi dapat dikemas menarik untuk menjadi sabun souvenir.

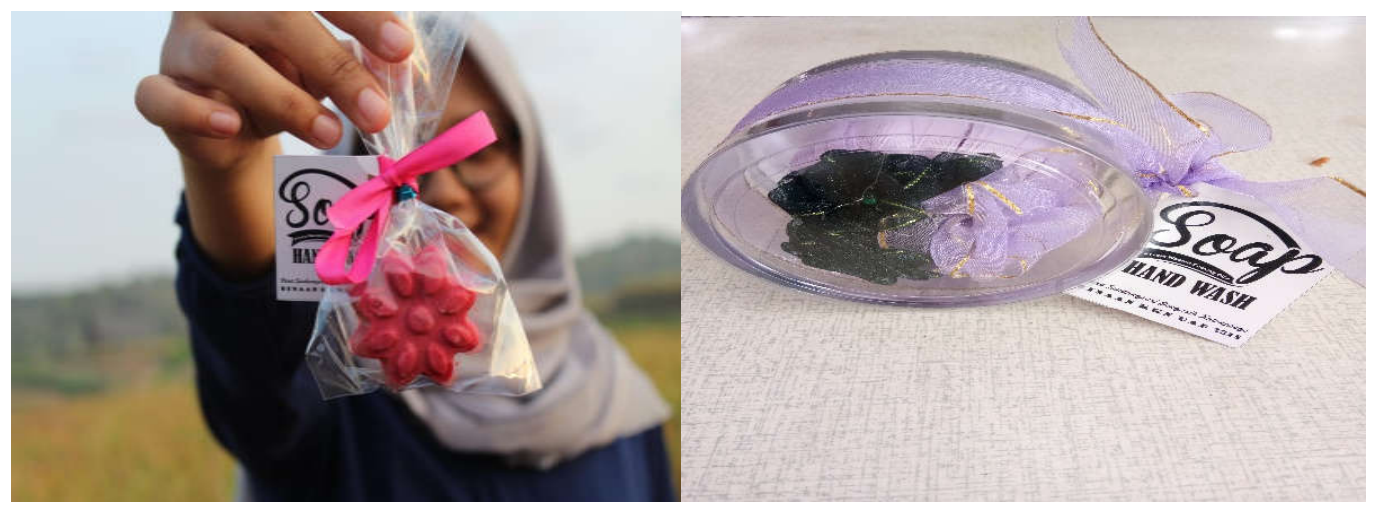

Gambar 1. Contoh produk sabun dari minyak jelantah

Pelaksanaan kegiatan pelatihan pembuatan sabun dari limbah minyak jelantah dan limbah kulit pisang ini sangat berdampak pada perubahan pola hidup masyarakat seperti, pengurangan pembuangan limbah minyak jelantah menjaga kelestarian lingkungan, kesehatan maupun meningkatkan sumber pendapatan masyarakat. Jika ditinjau dari segi ekonomis minyak jelantah dan limbah kulit pisang yang semula tidak bernilai jual kini memiliki nilai jual. Berdirinya UMKM menjadikan produk sabun souvenir dapat berjalan secara sistematis dan berkelanjutan baik dari prooduksi maupun pemasaran.

Keunggulan produk sabun menggunakan minyak jelantah yang sudah dijernihkan dengan kulit pisang kepok yaitu tekstur sabun lebih padat dan tidak lembek dibandingkan dengan minyak goreng. Adapun kekurangannya yaitu penggunaan pewangi komposisinya lebih banyak dibandingkan dengan minyak goreng. 
Teknis pemasaran produk sabun diantaranya: (1) menjalin kerjasama dengan pemerintah untuk memperkenalkan produk sabun dengan mengadakan gelar produk di berbagai kegiatan yang ada di desa, (2) menjalin kerjasama dengan berbagai objek wisata di Kulonprogo, (3) memasarkan melalui media on line dengan membuatkan web dan Instagram. Langkah tersebut tentunya dapat meningkatkan pangsa pasar baik local maupun nasional.

\section{KESIMPULAN DAN SARAN}

Pelaksanaan kegiatan pelatihan pembuatan sabun ini sangat membantu masyarakat untuk memanfaatkan limbah minyak jelantah berbasis zero waste industry. Kegiatan tersebut mengurangi resiko pencemaran air tanah. Sabun yang sudah diolah pun dapat menjadi barang bernilai ekonomis, selain itu pengurangan pembuangan limbah minyak jelantah menjaga kelestarian lingkungan, kesehatan maupun meningkatkan sumber pendapatan masyarakat.

Kegiatan tersebut perlu dikembangkan di berbagai daerah agar dapat meningkatkan kepedulian masyarakat terhadap limbah minyak jelantah dan kulit pisang untuk diolah kembali menjadi barang bernilai jual berbasis zero waste industry. Limbah yang semula tidak bernilai bahkan dapat merusak lingkungan kini menjadi barang bernilai ekonomis

\section{UCAPAN TERIMA KASIH}

Pemberdayaan masyarakat Desa Sendangsari dalam pengolahan limbah minyak jelantah dan limbah kulit pisang menjadi sabun merupakan hibah Kemenristekdikti skim KKN-PPM pendanaan tahun 2018. Hibah dari Kemenristekdikti sangat membantu kami dalam melaksanakan tridarma perguruan tinggi yaitu pengabdian kepada masyarakat. Pendanaan yang diberikan sangat bermanfaat bagi masyarakat Desa Sendangsari, Pengasih, Kulon Progo, Yogyakarta. Kegiatan KKN PPM ini juga didukung penuh oleh Lembaga Penelitian dan Pengabdian Masyarakat Universitas Ahmad Dahlan.

\section{DAFTAR PUSTAKA}

Aminah, S. (2010). Bilangan Peroksida Minyak Goreng Curah dan Sifat Organoleptik Tempe pada Pengulangan Penggorengan. Jurnal Pangan dan Gizi, Vol. 01(1), 710.

Kasyfita, N. (2007). Efektivitas Penggunaan Adsorben Kulit Pisang Kepok (Musanormalis) dalam Meningkatkan Kualitas Minyak Goreng Bekas. Jurnal Kimia Mulawarman, Vol. 04(2), 19-25. 
Putra, A. (2012). Recovery Minyak Jelantah Menggunakan Mengkudu Sebagai Absorben. Prosiding Seminar Nasional PERTETA. Malang: Fakultas Tekonologi Pertanian, Universitas Brawijaya.

Suryandari, E. S. (2014). Pelatihan Pemurnian Minyak Jelantah Dengan Kulit Pisang Kepok (musa paradisiacal, linn) untuk Pedagang Makanan di Pujasera Ngaliyan. Dimas: Jurnal Pemikiran Agama Untuk Pemberdayaan, Vol. 14(1), 57-70.

Yusuf, Y. (2010). Penyuluhan dan Pelatihan Pemanfaatan Limbah Minyak Goreng (Minyak Jelantah) Sebagai Bahan Baku Pembuatan Sabun Cair. Warta Pengabdian Andalas, Vol. 16(25), 195-206.

C 2018 Oleh authors. Lisensi Jurnal Solma, LPPM-UHAMKA, Jakarta. Artikel ini bersifat open access yang didistribusikan di bawah syarat dan ketentuan Creative Commons Attribution (CC BY) license (http://creativecommons.org/licenses/by/4.0/). 